\title{
Bibliometric Analysis of Soil Nutrient Research between 1992 and 2020
}

\author{
Xiaoyan Pan ${ }^{1}$, Jialong Lv ${ }^{1,2}$, Miles Dyck ${ }^{3}$ and Hailong He ${ }^{1, *(D)}$ \\ 1 College of Natural Resources and Environment, Northwest A\&F University, Yangling 712100, China; \\ pxy520@nwafu.edu.cn (X.P.); lj111@nwsuaf.edu.cn (J.L.) \\ 2 Key Laboratory of Plant Nutrition and the Agric-Environment in Northwest China (Ministry of Agriculture), \\ Northwest A\&F University, Yangling 712100, China \\ 3 Department of Renewable Resources, University of Alberta, Edmonton, AB T6G 2E3, Canada; \\ miles.dyck@ualberta.ca \\ * Correspondence: hailong.he@hotmail.com
}

Citation: Pan, X.; Lv, J.; Dyck, M.; He, H. Bibliometric Analysis of Soil Nutrient Research between 1992 and 2020. Agriculture 2021, 11, 223. https://doi.org/10.3390/agriculture 11030223

Academic Editors: Pavel Krasilnikov, Miguel A. Taboada and Amanullah

Received: 1 February 2021

Accepted: 4 March 2021

Published: 8 March 2021

Publisher's Note: MDPI stays neutral with regard to jurisdictional claims in published maps and institutional affiliations.

Copyright: (c) 2021 by the authors. Licensee MDPI, Basel, Switzerland. This article is an open access article distributed under the terms and conditions of the Creative Commons Attribution (CC BY) license (https:// creativecommons.org/licenses/by/ $4.0 /)$.

\begin{abstract}
Soil nutrient balance is related to the interaction mechanism between soil fertilizer, soil water, climate change, and plant capability. This paper provides a perspective from bibliometric analysis based on data from the Web of Science core collection with software tools, including Vosviewer, HistCite Pro, and Citespace, in order to reveal the evolution of research trends in soil nutrients. The results show that publication outputs have increased exponentially from 1992 to 2020. The synthetic parameter of the sum of normalized data (SND), calculated from the default indicators of the bibliometric software tools, was used to rank the overall contribution of journal/authors/institutions/countries. The results demonstrate that Agriculture Ecosystems E Environment, Soil Biology E Biochemistry and Science of the Total Environment are the leading journals in the soil nutrient field. The Chinese Academy of Sciences had the highest total citations and collaborated most closely with other organizations, followed by United States Department of Agriculture (USDA) Agricultural Research Service (ARS) and Agr\& Agri Food Canada. In addition, USA, China, and UK are the top three research centers for this topic. Moreover, Ken E Giller, Qirong Shen, and Rattan Lal were the top three authors, while Andrew Sharpley ranked the first depending on citations per publication. In terms of co-occurrence of keyword analysis, the results indicate that nitrogen fertilizer, green manure, and soil population have gained close attention from scholars, while soil amendment of biochar have evolved as a hot topic in recent years. Perspectives on future studies are also given.
\end{abstract}

Keywords: soil nutrient; bibliometric; visualization; citations; publication outputs

\section{Introduction}

Soil nutrients are a critical factor determining crops growth [1,2], soil microbial activity [3,4], and potential environmental pollution [5-7]. The availability of soil nutrients is not only related to the absorption capacity of crops [8], but it is also related to the transformation, migration, and microbial decomposition of fertilizer in soil [9-11]. Soil nutrient balance is closely related to the concentration or proportion of soil fertilizers (e.g., nitrogen-N, phosphate-P, potassium-K, or carbon/organic-C). Studies have shown that the concentration or ratio of main $\mathrm{N}-, \mathrm{P}-$, and $\mathrm{K}$-fertilizer in topsoil can be used as a good indicator illustrating soil nutrient status and can serve as the basis for calculating soil nitrogen content [12]. In addition, soil nutrients are closely linked to microbial community composition, which could impact on soil environment. Studies have shown that nitrogen status should be an important factor for sustainable agricultural management [13], while organic manure, applied alone or in combination with chemical fertilizers, would increase the soil fertility and functional diversity of soil microbial communities [14]. Generally, nitrogen deposition could change microbial community composition $[15,16]$, and nitrogen addition significantly reduced microbial community diversity and changed bacteria and 
fungi communities [17]. Furthermore, the most commonly accumulated nitrogen or sulfur fertilizer exists in the form of nitrates or sulfate (S) in soil [18-20], which likely leads to aggravated secondary salinization insoil layer $[8,21,22]$. The aggravated secondary salinization may result in decreased availability of soil fertilizers, inhibiting the productivity of crops such as cotton [23,24], sunflower [25,26], and maize [22,27]. To some extent, soil; $\mathrm{N}-, \mathrm{P}-, \mathrm{K}-$, and C-fertilizer; and the microbial community significantly affect plant growth and soil environment. Nonetheless, soil nutrient balance is difficult to achieve as soil fertilizer aims to maximize economic benefit. An overdose of N-, P-, K, -or S-fertilizer leads to soil pollution and plant poisoning, while insufficient fertilizer applications cannot meet the needs of plant growth, which leads to declined yield and quality due to plant malnutrition [28-30]. Therefore, the appropriate use of soil nutrient plays a vital role in sustainable soil ecological environment and the growth of plants.

Numerous studies have been conducted on soil nutrients field. However, no attempt has been made to provide a whole picture of the research status on soil nutrients from a bibliometric perspective. Bibliometrics or scientometrics is a quantitative analysis method based on mathematical statistics [31]. It has been widely applied to analyze research hotpots and development trends of a specific field. For instance, researchers have analyzed global research based on bibliometric reviews on soil moisture [32], soil environment [33-35], soil microplastics [36], soil hydrothermal properties [37], soil micro-morphological [38], soil pollution [39], soil health [40], and soil remediation [41-43]. In order to better understand the current research status of soil nutrient research, the scientometric review is adopted, which is conducive to show hot research topics in this field and their evolution. Perspectives are also given to promote further studies to fill knowledge gaps.

\section{Material and Methods}

The datasets on soil nutrient were searched from the database of the Web of Science Core Collection (WoSCC), including the Science Citation Index Expanded (SCI-EXPANDED, since 1992) and Social Sciences Citation Index (SSCI, since 2004). The data from January 1992 to December 2020 were downloaded from the WoSCC for analysis. The query sets used in the advanced search mode of WoSCC collection were: TS = " "soil fertility" OR "soil nutrient" OR "soil nutrition" OR "soil fertilizer" OR "soil fertilization" OR "plant nutrient" OR "plant nutrition" OR "chemical fertilizer" OR "organic fertilizer" OR "green manure" OR "inorganic fertilizer" OR "mineral fertilizer" OR "nitrogen fertilizer" OR "phosphorus fertilizer" OR "potassium fertilizer" OR "calcium fertilizer" OR "magnesium fertilizer" OR "sulphur fertilizer" OR "micronutrient fertilizer" OR "fertilizer with inhibitor" OR "Controlled-Release Fertilizer" OR "Slow-release fertilizer" OR "dry fertilizer" OR "Watersoluble Fertilizer") OR TS = ((compost OR manure OR "sewage sludge") AND (agricultur* OR farmland OR grassland OR forest OR ecosystem)), where TS indicates "topics" in Web of Science. Document types of publications containing "Article" OR "Book" OR "Book Chapter" OR "Data Paper" OR "Database Review" OR "Letter" OR "Note" OR "Review" written in English were retained. The resulted documents were exported as a text file with the "full record and citation data" for bibliometric analysis. This returned a total number of 51,640 publications.

Data visualization was analyzed using software tools containing the VOSviewer 1.6.15, HistCite Pro, and CiteSpace 5.6.R3. VOSviewer, as a freely available computer program, is developed for constructing and viewing bibliometric maps, and is especially useful for displaying large bibliometric maps in an easy-to-interpret way [44]. The co-authorship of authors/organizations/countries was performed using the VOSviewer. The full counting method was used in this paper, and publications with maximum 25 authors per document were kept for analysis by default. The default settings excluded 1232 publications for analysis that exceeded 25 authors per article. HistCite Pro, a modified version based on the original HistCite, was sorted the leading status of authors/institutions/countries depending on total global citation (TGCS) and total local citations (TLCS) [45]. CiteSpace can be applied to track the development of a field closely and extensively and provide a net- 
work analysis, which is used for the treatment and presentation of results [46]. Keywords with the strongest burst citations were found using CiteSpace, which vividly showed the research topics in this field. Figures in this study were produced using VOSviewer 1.6.15, Origin 2021, and Arc GIS 10.8.

In order to rank the overall contributions of journals/authors/institutions/countries and to eliminate the dimensional influence among indicators provided by the bibliometric software tools, the sum of normalized data (SND) method was adopted [47]:

$$
\begin{gathered}
S D=\frac{\left(X-X_{\min }\right)}{\left(X_{\max }-X_{\min }\right)} \\
S N D=S D_{1}+S D_{2}+\cdots S D_{n}
\end{gathered}
$$

where $X_{\max }$ and $X_{\min }$ are the maximum and minimum value of sample data, respectively, and $n$ represents different indicators.

\section{Results and Discussion}

\subsection{Publication Outputs Analysis over the Years}

The annual number of publications and citations per paper between 1992 and 2020 are shown in Figure 1. The number of publications increased significantly from 1992 to 2020, from 480 publications in 1992 to 4614 in 2020. This is similar to results from previous studies pertaining to soil fertilizer [48] and soil monitoring [33]. The increasing trend may be attributed to the "green revolution" that is associated with the greater input of chemical fertilizer for greater yield [49-51], which intrigues scholars in the soil nutrient research field. In addition, easier access to online literature compared to library subscriptions since 1990 could be another reasons [32]. The number of citations per publication showed a fluctuated increasing trend from 1992 to 1998, reaching a peak value of 55.4 in 1998. It showed a decreasing trend thereafter, with only 1.1 in 2020. This value showed a general decreasing trend since 1999, especially after 2009, which could be attributed to the rapidly evolved research topics, high volume of publications, and shorter time for accumulating citations [32]. The trend of citations per publication was basically similar with the study result for soil fertilizer (from 2007 to 2016, there was a decreasing trend) [48].

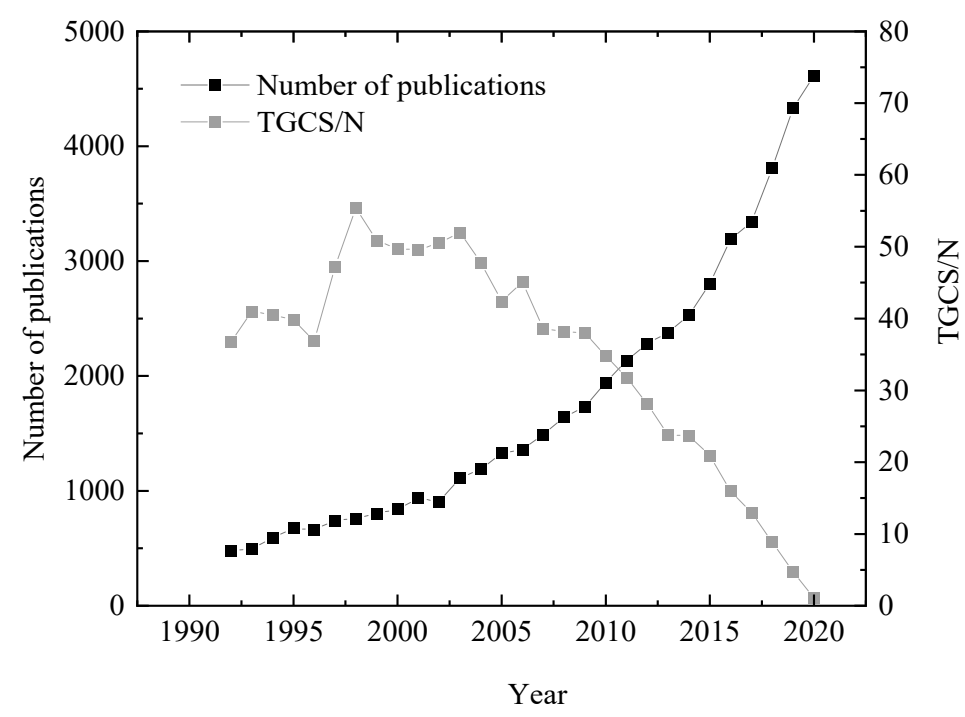

Figure 1. Annual number of publications and citations per article in soil nutrient field from 1992 to 2020.

\subsection{Analysis of Primary Journals}

A total of 2498 journals published research on soil nutrients. The top 10 productive journals are shown in Figure 2. Communications in Soil Science and Plant Analysis (1239 publications) made the highest contributions to the total number of publications, accounting for 
$14.4 \%$ of total publications, followed by Science of the Total Environment (1106 publications), Agriculture Ecosystems \& Environment (1071 publications), and Plant and Soil (1061 publications), each accounting for 12 13\%. There were no significant differences among the other five journals, including the Journal of Environmental Quality (760 publications), Soil Biology \& Biochemistry (740 publications), Journal of Plant Nutrition (700 publications), Nutrient Cycling in Agroecosystems (678 publications), and the Agronomy Journal (667 publications) in terms of the total number of publications.

According to Table 1, Agriculture Ecosystems \& Environment had the maximum TLCS $(=12,048)$ and TGCS $(=46,115)$. There was a large gap when Agriculture Ecosystems $\mathcal{E}$ Environment was compared to Communications in Soil Science and Plant Analysis (with TLCS $=2407$ and TGCS $=9917$ ). Science of the Total Environment has the greatest impact factor according to Journal Citation Report in 2019 (IF2019 $=6.6$ ) and the greatest TGCS per year (TGCS/ $t=4173$ ). There was a significant difference when Science of the Total Environment was compared to Communications in Soil Science and Plant Analysis (IF2019 $=0.767$ and TGCS $/ t=741$ ) and the Journal of Plant Nutrition (IF2019 $=1.132$ and TGCS $/ t=522)$. In addition, publications in Soil Biology \& Biochemistry were highly cited with 58.9 citations per article, ranking first among journals (data not shown). According to synthetic parameter (sum of normalized data (SND)), Agriculture Ecosystems \& Environment ranked the first with $\mathrm{SND}=4.30$, followed by Soil Biology \& Biochemistry with SND $=3.72$ and Science of the Total Environment with $\mathrm{SND}=3.70$. Therefore, they are the leading journals in this field.

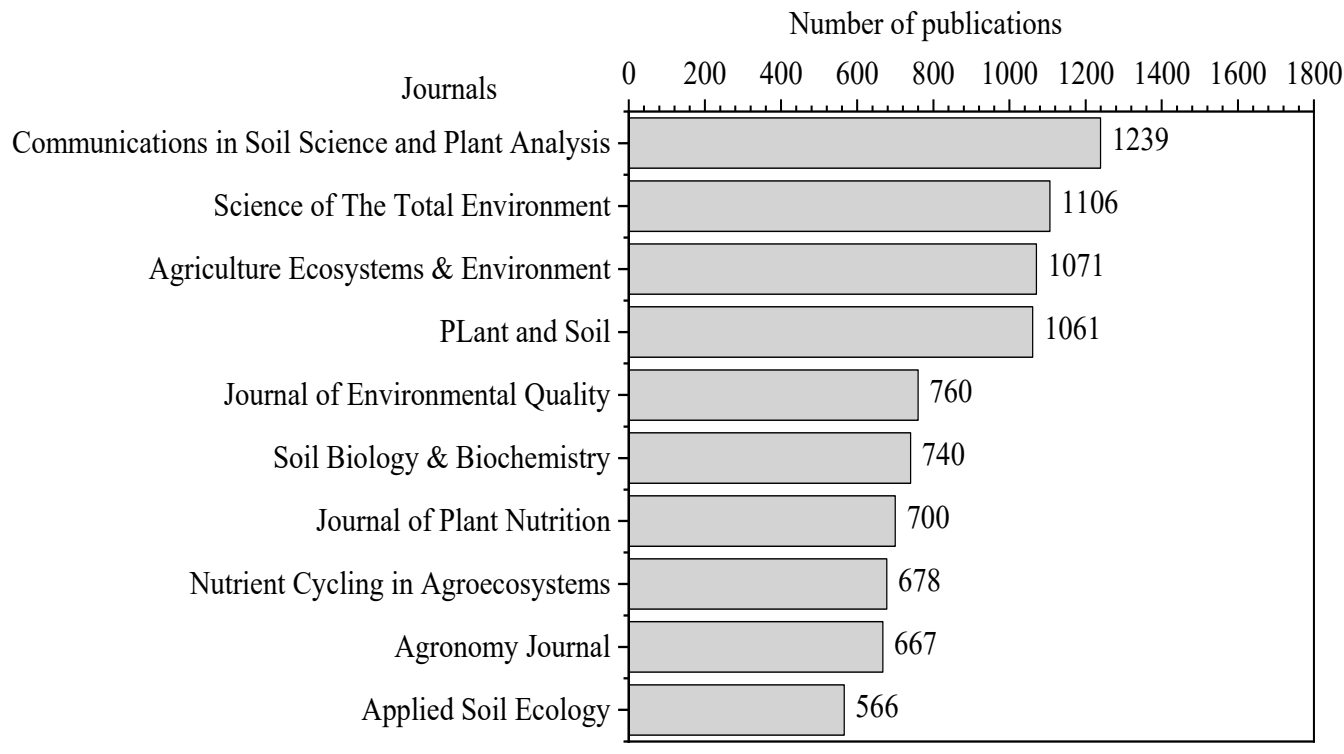

Figure 2. Top 10 productive journals in soil nutrition research between 1992 and 2020.

Table 1. Top 10 productive journals in soil nutrition research between 1992 and 2020.

\begin{tabular}{|c|c|c|c|c|c|c|}
\hline Journals & $\mathbf{N}$ & TLCS & TGCS & IF & TGCS/t & SND \\
\hline Communications in Soil Science and Plant Analysis & 1239 & 2407 & 9917 & 0.767 & 741 & 1.25 \\
\hline Science of the Total Environment & 1106 & 5219 & 27,645 & 6.551 & 4173 & 3.70 \\
\hline Agriculture Ecosystems \& Environment & 1071 & 12,048 & 46,115 & 4.241 & 3972 & 4.30 \\
\hline Plant and Soil & 1061 & 9200 & 43,105 & 3.299 & 3164 & 3.56 \\
\hline Journal of Environmental Quality & 760 & 8761 & 34,148 & 2.142 & 2140 & 2.36 \\
\hline Soil Biology \& Biochemistry & 740 & 9955 & 43,600 & 5.795 & 3612 & 3.72 \\
\hline Journal of Plant Nutrition & 700 & 1308 & 6524 & 1.132 & 522 & 0.26 \\
\hline Nutrient Cycling in Agroecosystems & 678 & 7162 & 20,013 & 2.45 & 1390 & 1.58 \\
\hline Agronomy Journal & 667 & 4458 & 16,512 & 1.683 & 1192 & 1.04 \\
\hline Applied Soil Ecology & 566 & 3857 & 14,952 & 3.187 & 1540 & 1.15 \\
\hline
\end{tabular}

Note: TLCS, total global citation; TGCS, total local citations; IF, Journal impact factor trend 2019; TGCS/t, total global citation per year; SND, sum of normalized data (original data used for calculating SND include N (number of publications), TLCS, TGCS, IF, and TGCS/t). 


\subsection{Analysis of Authors, Institutions, and Countries}

When 20 was set as the minimum number publications per author using the VOSviewer, the co-authorship network map of authors included 222 authors who had 2003 total link strength (TLS) and obtained 183 clusters closely linking with each other. However, some labels did not show due to overlap. For example, label of Christie Peter (China Agricultural University, China) in the dark blue network was overlapped by the label of Ken E Giller (Wageningen University, Netherlands) in the pink network (Figure 3). Among others, it was found Ken E Giller with 147 publications, Qirong Shen (Nanjing Agricultural University, China) with 133 publications, and Rattan Lal (Ohio State University, USA) with 131 publications were the top three productive researchers in soil nutrient field (Figure 3 and Table 2). In recent years, Ken E Giller is among the most active researcher in the topic of soil fertilizer [52-54]. Giller's publications were highly cited [55], accounting for $19 \%$ of 9647 total citations (Table 2). Rattan Lal (Ohio State University, USA) has focused on surface layer of carbon and nitrogen [56], the soil-plant system [57], and the variability of soil organic matter [58]. These papers had profound influence on the soil nutrient field because of their higher citations [59,60], accounting for $42 \%$ of 11,097 total citations (Table 2). It is noteworthy that papers written by Andrew Sharpley also obtained higher citations [61,62], accounting for $39 \%$ of 11,565 total citations (Table 2). The results indicate that these highly cited papers play a very important role in soil nutrition field, and the authors (Ken E Giller, Rattan Lal, and Andrew Sharpley) play a role in advancing this field. In addition, Andrwe Sharpley and Rattan Lal are the most influential figures in the soil nutrient field due to their high total citations and citations per publication (Table 2). For instance, each publications of Andrew Sharpley was cited 132.9 times on average, which was significantly higher than others. Recently, Andrew Sharpley has been the most active researcher on topic of soil phosphorus fertilizer loss [63-65] and agricultural soil pollution [66], while he has not been closely linked with others. Qirong Shen ranked the first in terms of collaborating with other authors, with the greatest TLS of 846, followed by Bernard Vanlauwe (International Institute of Tropical Agriculture, Nigeria) with TLS = 545, Ken E Giller with TLS = 543, and Minggang Xu (Chinese Academy of Agricultural Sciences, China) with TLS = 513 (Figure 3 and Table 2). According to synthetic parameter of SND, Ken E Giller ranked first with $\mathrm{SND}=2.32$, followed by Rattan Lal with SND $=2.16$, Qirong, Shen with SND $=2.15$, and Andrew Sharpley with SND $=1.37$ (Table 2). These scholars are the top influential authors in this field.

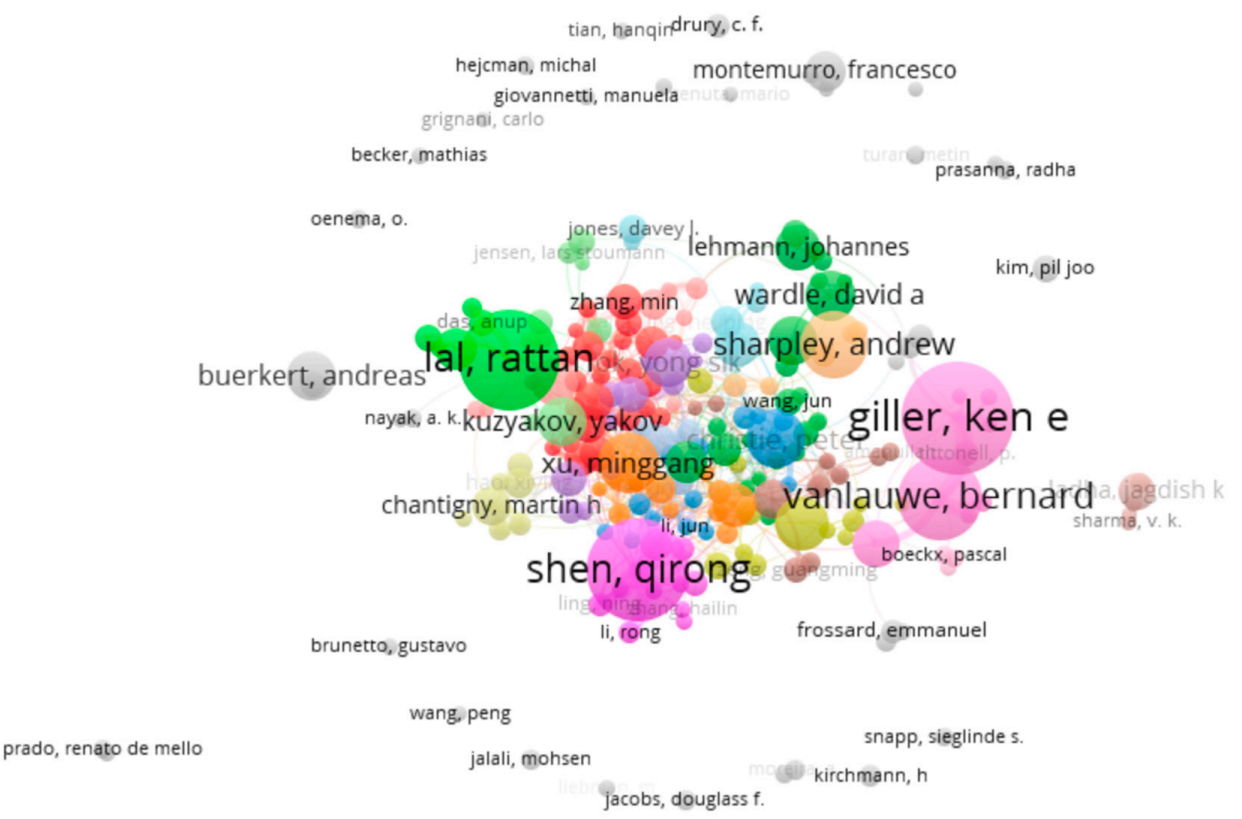

Figure 3. The network map of co-authorship analysis of authors between 1992 and 2020. 
Table 2. Top 10 productive authors/institutions/countries in soil nutrition research from 1992 to 2020.

\begin{tabular}{|c|c|c|c|c|c|c|}
\hline NO. & Items & $\mathbf{N}$ & TC & TLS & SND & TC/N \\
\hline \multicolumn{7}{|c|}{ Top 10 Authors } \\
\hline 1 & Giller, Ken E. (Wageningen University, Netherlands) & 147 & 9647 & 543 & 2.32 & 65.6 \\
\hline 2 & Shen, Qirong (Nanjing Agricultural University, China) & 133 & 4326 & 846 & 2.15 & 32.5 \\
\hline 3 & Lal, Rattan (Ohio State University, USA) & 131 & 11,097 & 478 & 2.16 & 84.7 \\
\hline 4 & Vanlauwe, Bernard (Int Inst Trop Agr, Nigeria) & 108 & 4339 & 545 & 1.36 & 40.2 \\
\hline 5 & Sharpley, Andrew (University Arkansas, USA) & 87 & 11,565 & 292 & 1.37 & 132.9 \\
\hline 6 & Xu, Minggang (CAAS, China) & 77 & 2155 & 513 & 0.73 & 28.0 \\
\hline 7 & Christie, Peter (China Agricultural University, China) & 76 & 2677 & 415 & 0.60 & 35.2 \\
\hline 8 & Olesen, Jorgen E. (Aarhus University, Denmark) & 68 & 2306 & 279 & 0.25 & 33.9 \\
\hline 9 & Wardle, David A. (Nanyang Technol University, Singapore) & 64 & 3909 & 262 & 0.32 & 61.1 \\
\hline 10 & Buerkert, Andreas (University Kassel, Germany) & 63 & 978 & 241 & 0.00 & 15.5 \\
\hline 11 & Kuzyakov, Yakov (University Gottingen, Germany) & 63 & 1559 & 369 & 0.27 & 24.7 \\
\hline 12 & Ok, Yong Sik (Korea University, Korea) & 63 & 4178 & 390 & 0.55 & 66.3 \\
\hline \multicolumn{7}{|c|}{ Top 10 organizations } \\
\hline 1 & Chinese Academy of Sciences (China) & 2579 & 61,078 & 2069 & 3.00 & 23.7 \\
\hline 2 & USDA ARS (USA) & 1577 & 55,055 & 1214 & 1.92 & 34.9 \\
\hline 3 & Agr\& Agri Food Canada (Canada) & 880 & 25,193 & 473 & 0.61 & 28.6 \\
\hline 4 & University Chinese Academy Sciences (China) & 735 & 8160 & 984 & 0.50 & 11.1 \\
\hline 5 & University Florida (USA) & 693 & 20,361 & 377 & 0.37 & 29.4 \\
\hline 6 & Chinese Academy of Agricultural Sciences(China) & 687 & 13,336 & 671 & 0.40 & 19.4 \\
\hline 7 & China Agricultural University (China) & 665 & 13,839 & 608 & 0.37 & 20.8 \\
\hline 8 & Swedish University Agricultural Sciences (Sweden) & 550 & 22,033 & 275 & 0.28 & 40.1 \\
\hline 9 & Wageningen University (Netherlands) & 527 & 18,042 & 346 & 0.23 & 34.2 \\
\hline 10 & Nanjing Agricultural University (China) & 514 & 14,712 & 354 & 0.17 & 28.6 \\
\hline \multicolumn{7}{|c|}{ Top 10 countries } \\
\hline 1 & USA & 10,789 & 399,320 & 5876 & 3.00 & 37.0 \\
\hline 2 & China & 8772 & 165,595 & 4472 & 1.83 & 18.9 \\
\hline 3 & India & 3264 & 58,926 & 959 & 0.20 & 18.1 \\
\hline 4 & UK & 3197 & 140,102 & 4384 & 1.12 & 43.8 \\
\hline 5 & Germany & 3079 & 108,578 & 3457 & 0.83 & 35.3 \\
\hline 6 & Canada & 2909 & 88,035 & 1858 & 0.43 & 30.3 \\
\hline 7 & Brazil & 2698 & 42,463 & 1476 & 0.20 & 15.7 \\
\hline 8 & Australia & 2516 & 94,612 & 2635 & 0.56 & 37.6 \\
\hline 9 & Spain & 2362 & 69,576 & 1823 & 0.31 & 29.5 \\
\hline 10 & Italy & 1852 & 45,912 & 1500 & 0.12 & 24.8 \\
\hline
\end{tabular}

Note: $\mathrm{N}$, total number of publications; TC, total citations; TLS, total link strength; TC/N (equal to TGCS/N), citations per publication. Int Inst Trop Agr, International Institute of Tropical Agriculture; CAAS, Chinese Academy of Agricultural Sciences. SND, sum of normalized data (original data include N, TC, and TLS).

When 100 was set as the threshold of the minimum number of publications per institution or per country, institutions were grouped into 144 clusters with TLS $=11,078$, and countries were grouped into 73 clusters with TLS $=28,376$. The top 10 most contributing institutions in this field are shown in Table 2. It was found that the ChineseAcademy of Sciences (China), with 2579 publications, made the most contributions, followed by the USDA ARS (USA), with 1577 publications. Agr\& Agri Food Canada (Canada) had 880 publications, the University of Chinese Academy Sciences (China) had 735 publications, and the University of Florida (USA) had 693 publications. The top two institutions with the greatest total publication citations were the Chinese Academy of Sciences and the USDA ARS, with 61,078 and 55,055 citations, respectively. Their citations were considerably higher than other institutions, while per article citations of the Chinese Academy of Sciences were only 23.7, ranking sixth among the top 10 institutions. In addition, the Chinese Academy of Sciences was the most active organization that was in close connection with others, as indicated by the greatest total link strength of 2069. Although the number of publications for the Swedish University of Agricultural Sciences (Sweden) and Wageningen University (Netherlands) were only 550 and 527, respectively, roughly accounting for $1.0 \%$, their 
respective per article citations were 40.1 and 34.2, ranking first and third. The Chinese Academy of Sciences obtained the greatest SND of 3.00, and the USDA ARS ranked second with SND $=1.92$. Their SND were much greater than other organizations, which may indicate that the Chinese Academy of Sciences and the USDA ARS are the most impactful organizations in this field.

The top 10 most contributing countries in this field are shown in Table 2, and the distribution map of number of publications for the 180 contributing countries are shown in Figure 4. USA (with 10,789 publications) was the most productive country, accounting for $20.9 \%$ of the total publications, while the second most contributing country was China (with 8772 publications), accounting for $17.0 \%$. The number of publications for the other top 10 countries was relatively small compared to USA and China, ranging from 3264 for India to 1852 publications for Italy. There were big differences in the total citations among countries as well. UK ranked the first in per publication citations with $\mathrm{TC} / \mathrm{N}=43.8$. The most productive country, USA, ranked third with $\mathrm{TC} / \mathrm{N}=37$, and China ranked eight with $\mathrm{TC} / \mathrm{N}=13.0$. In addition, USA, China, and UK, with TLS $=5876,4472$, and 4384, respectively, were the most active countries in international collaboration. In addition, India showed a weaker international collaboration. USA, China, and UK were the top three countries leading soil nutrient studies according to SND.

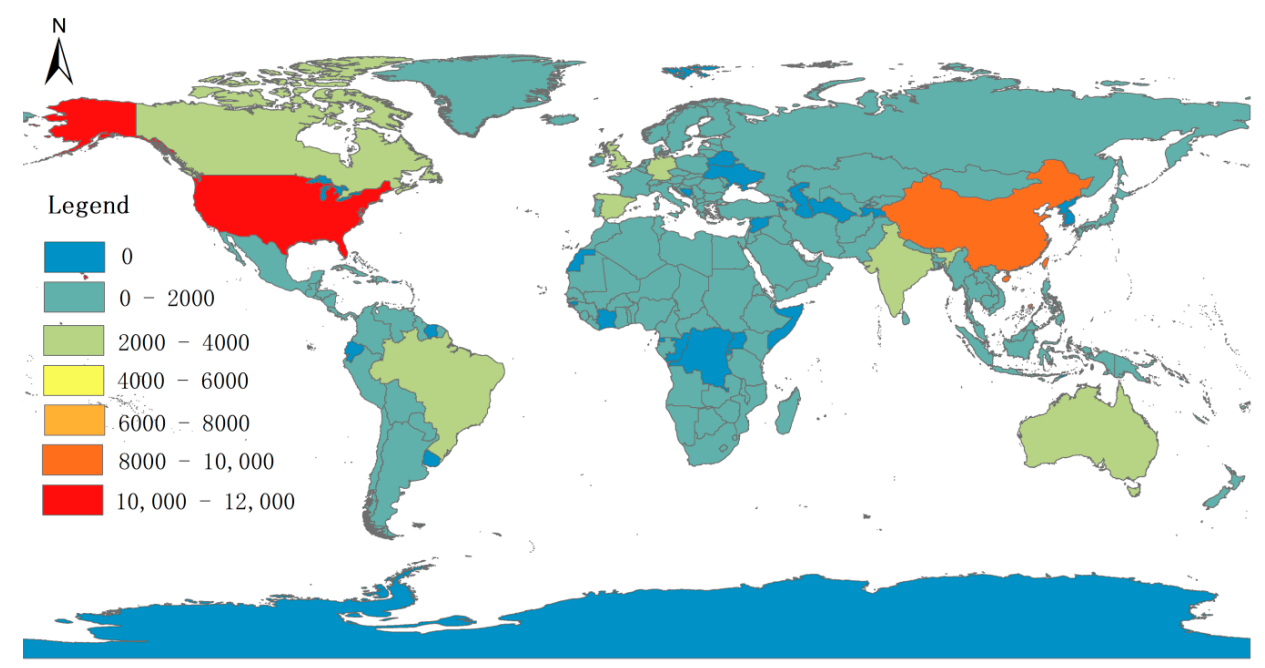

Figure 4. The distribution map of number of publications of countries between 1992 and 2020 .

\subsection{Analysis of Keywords}

Keyword burst detection in the documents was analyzed by the CiteSpace to illustrate research hot spots in a specific period. The red dotted lines in Figure 5 are heat bars, representing the time period with the strongest citation bursts [67]. Hot topics of soil nutrient field could be divided into three stages: (1) The topic of soil nitrogen (with keywords of nitrate, $\mathrm{N}^{15}$, denitrification, nitrogen fixation, ammonium, and aluminum) and crop (corn, tree and legume) became a research hot spot between 1992 and 2009. During this period, there were many theoretical studies on soil nutrition [68-71]. The relationships between soil fertilizers and plants were also gradually studied by scholars [72-74]. (2) The research directions were then gradually shifted to focus on soil pollution (with keywords of loss, litter, and population), forest (e.g., agroforestry, forest soil, and deforestation), and farmland manure (e.g., cattle slurry and broiler litter). The hot study region and climate was West Africa and Savanna, respectively. Scholars were interested in the research of maintaining soil fertility in West Africa [75,76], likely with the goal of improving the environment and the inherent poor soil fertility in West Africa [76], which could increase crop yield and reduce starvation and malnutrition [77,78]. (3) Between 2015 and 2020, soil health (including charcoal, biochar, and physicochemical property) and ecosystem service (e.g., biochar, physicochemical property, greenhouse gas emission, and pyrolysis temperature) 
became the hot research topics due to the increased concern on agricultural sustainability with the goal of food security. Our analysis indicated that soil nitrogen fertilizer, soil pollution, and soil health are of great importance in soil nutrient field. Scholars have tried to find the best solutions for soil pollution, using farmyard manure, bacteria, and biochar to remediate/reclaim soil properties [79-81]. These papers included topics of nitrogen fertilizer [61], nitrate [82], green manure [83], nitrogen loss [84], biochar [85], and microbial communities [86], which obtained higher citations. Biochar can impact soil biota [85], and microorganisms play a regulating role in soil nutrition [87-89], as they have reinforced soil nutrition health $[90,91]$. Therefore, these themes of nitrogen fertilizer, green manure, biochar, and microbial communities have been favored by authors. The soil remediation of biochar may become a breakthrough in the management of soil nutrients, as it had highest strength burst (Figure 5).

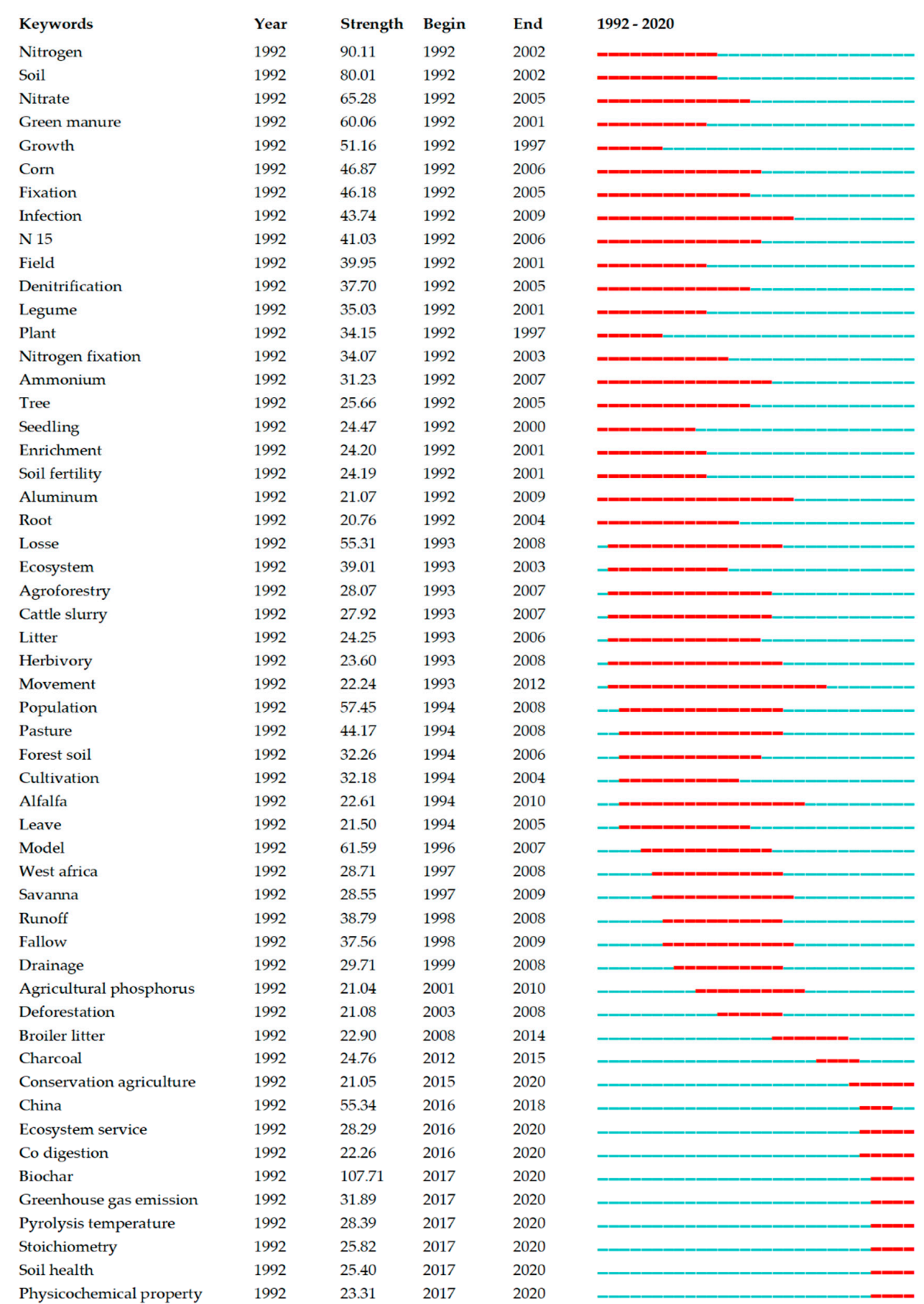

Figure 5. Top 54 keywords with the strongest citation bursts in soil nutrition research from 1992 to 2020. 


\section{Conclusions}

The scientific literature data on soil nutrient were analyzed from scientometric perspectives. The results showed that the number of publications has increased remarkably from 1992 to 2020, while per article citations peaked in 1998 and then dropped during 1992-2020. Agriculture Ecosystems \& Environment, Soil Biology \& Biochemistry and Science of the Total Environment were the leading journals in this field. The Chinese Academy of Sciences (China) and USDA ARS (USA) made the most contributions to number of publications and total link strength, having strong collaborations with other institutions. USA and China were the top two contributing countries and had close cooperative relationships with others. USA was the most influential country according to its greatest total citations. The authors Ken E Giller from Netherlands, Qirong Shen from China, and Rattan Lal from USA were the leading authors in terms of the number of publications. Andrew Sharpley from USA was as the leading author in terms of the total citations and per article citations. For keyword analysis, soil nitrogen fertilizer, green manure, and soil population are ongoing hot topics because of their strongest burst strength in recent years. Recently, soil health, as indicated by keywords of microbial communities and amendment soil of biochar, has been paid close attention by researchers. For the sake of resilience to climate change and to increase the sustainability of soil productivity, the regenerative agriculture that aims to regenerate topsoil, increase biodiversity, improve the water cycle, enhance the ecosystem service, support biosequestration, and strengthen the health and vitality of farm soils could be among the future hot topics [92].

Author Contributions: Conceptualization, H.H.; methodology, M.D. and J.L.; software, X.P.; validation, H.H. and J.L.; formal analysis, X.P.; investigation, X.P.; resources, J.L.; data curation, X.P.; writing—original draft preparation, X.P.; writing—review and editing, H.H., J.L. and M.D.; visualization, X.P.; supervision, J.L.; project administration, J.L.; funding acquisition, M.D., H.H. and J.L. All authors have read and agreed to the published version of the manuscript.

Funding: Funding for this research was provided in part by National Key Research and Development Program of China (2017YFD0200205), the Northwest A\&F University (Youth talent training program), and the 111 project (No. B12007).

Institutional Review Board Statement: Not applicable.

Informed Consent Statement: Not applicable.

Data Availability Statement: Not applicable.

Acknowledgments: The authors also greatly appreciate the valuable and insightful comments by the editor and anonymous reviewers.

Conflicts of Interest: The authors declare no conflict of interest.

\section{References}

1. Rosolem, C.A.; Foloni, J.S.S.; Tiritan, C.S. Root growth and nutrient accumulation in cover crops as affected by soil compaction. Soil Till. Res. 2002, 65, 109-115. [CrossRef]

2. Gao, D.; Zhou, X.; Duan, Y.; Fu, X.; Wu, F. Wheat cover crop promoted cucumber seedling growth through regulating soil nutrient resources or soil microbial communities? Plant Soil 2017, 418, 1-17. [CrossRef]

3. Allen, A.S.; Schlesinger, W.H. Nutrient limitations to soil microbial biomass and activity in loblolly pine forests. Soil Biol. Biochem. 2004, 36, 581-589. [CrossRef]

4. Alster, C.J.; German, D.P.; Lu, Y.; Allison, S.D. Microbial enzymatic responses to drought and to nitrogen addition in a southern California grassland. Soil Biol. Biochem. 2013, 64, 68-79. [CrossRef]

5. Finzi, A.C.; Austin, A.T.; Cleland, E.E.; Frey, S.D.; Houlton, B.Z.; Wallenstein, M.D. Responses and feedbacks of coupled biogeochemical cycles to climate change: Examples from terrestrial ecosystems. Front. Ecol. Environ. 2011, 9, 61-67. [CrossRef]

6. Bell, C.W.; Tissue, D.T.; Loik, M.E.; Wallenstein, M.D.; Acosta Martinez, V.; Erickson, R.A.; Zak, J.C. Soil microbial and nutrient responses to 7 years of seasonally altered precipitation in a Chihuahuan Desert grassland. Glob. Chang. Biol. 2014, 20, 1657-1673. [CrossRef] [PubMed]

7. Yang, L.; Huang, B.; Mao, M.; Yao, L.; Niedermann, S.; Hu, W.; Chen, Y. Sustainability assessment of greenhouse vegetable farming practices from environmental, economic, and socio-institutional perspectives in China. Environ. Sci. Pollut. Res. Int. 2016, 23, 17287-17297. [CrossRef] 
8. Zhang, X.; Davidson, E.A.; Mauzerall, D.L.; Searchinger, T.D.; Dumas, P.; Shen, Y. Managing nitrogen for sustainable development. Nature 2015, 528, 51-59. [CrossRef]

9. Pandey, R.N.; Rani, R.; Yeo, J.-E.; Spencer, M.; Hu, S.; Lang, R.A. The Eyes Absent phosphatase-transactivator proteins promote proliferation, transformation, migration, and invasion of tumor cells. Oncogene 2010, 29, 3715-3722. [CrossRef]

10. Jug, T.; Vesel, V. Migration of nutrients from soil to plant in olive orchards. Emir. J. Food Agric. 2015, 27, 215. [CrossRef]

11. Ren, T.; Bu, R.; Liao, S.; Zhang, M.; Li, X.; Cong, R.; Lu, J. Differences in soil nitrogen transformation and the related seed yield of winter oilseed rape (Brassica napus L.) under paddy-upland and continuous upland rotations. Soil Tillage Res. 2019, 192, 206-214. [CrossRef]

12. Entz, M.H.; Guilford, R.; Gulden, R. Crop yield and soil nutrient status on 14 organic farms in the eastern portion of the northern Great Plains. Can. J. Plant. Sci. 2001, 81,351-354. [CrossRef]

13. Liu, C.; Gong, X.; Dang, K.; Li, J.; Yang, P.; Gao, X.; Deng, X.; Feng, B. Linkages between nutrient ratio and the microbial community in rhizosphere soil following fertilizer management. Environ. Res. 2020, 184, 109261. [CrossRef] [PubMed]

14. Zhu, Z.; Bai, Y.; Lv, M.; Tian, G.; Zhang, X.; Li, L.; Jiang, Y.; Ge, S. Soil Fertility, Microbial Biomass, and Microbial Functional Diversity Responses to Four Years Fertilization in an Apple Orchard in North China. Hortic. Plant J. 2020, 6, 223-230. [CrossRef]

15. Matulich, K.L.; Weihe, C.; Allison, S.D.; Amend, A.S.; Berlemont, R.; Goulden, M.L.; Kimball, S.; Martiny, A.C.; Martiny, J.B.H. Temporal variation overshadows the response of leaf litter microbial communities to simulated global change. ISME J. 2015, 9, 2477-2489. [CrossRef] [PubMed]

16. Fan, G.; Li, Z.; Wang, S.; Huang, K.; Luo, J. Migration and transformation of nitrogen in bioretention system during rainfall runoff. Chemosphere 2019, 232, 54-62. [CrossRef] [PubMed]

17. Wei, H.; Wang, X.; Li, Y.; Yang, J.; Wang, J.; Lü, X.; Han, X. Simulated nitrogen deposition decreases soil microbial diversity in a semiarid grassland, with little mediation of this effect by mowing. Pedobiologia 2020, 80, 150644. [CrossRef]

18. Ahmadjian, V.; Hawksworth, D.L. Nitrogen and sulphur fertilization. Excess nitrates in the soil: A problem to be solved, and solutions under way. Taxon 1996, 99, 272-278.

19. Brito, J.M.C.; Ferreira, D.; Guerrero, C.A.C.; Machado, A.V.; Beltrão, J. Soil pollution by nitrates using sewage sludge and mineral fertilizers. Improv. Crop Qual. Nutr. Manag. 1999, 86, 223-227.

20. Vandenberghe, C.; Palm, R.; Lambert, R.; De Toffoli, M.; Marcoen, J.M. Implementation of the Nitrates Directive. analysis of the assessment's methodology for the control of the soil nitrate nitrogen residue in the farm's fields of Wallonia. Biotechnol. Agron. Soc. Environ. 2012, 16, 25-32.

21. Shen, W.; Ni, Y.; Gao, N.; Bian, B.; Zheng, S.; Lin, X.; Chu, H. Bacterial community composition is shaped by soil secondary salinization and acidification brought on by high nitrogen fertilization rates. Appl. Soil Ecol. 2016, 108, 76-83. [CrossRef]

22. Lu, P.; Zhang, Z.; Sheng, Z.; Huang, M.; Zhang, Z. Effect of Surface Straw Incorporation Rate on Water-Salt Balance and Maize Yield in Soil Subject to Secondary Salinization with Brackish Water Irrigation. Agronomy 2019, 9, 341. [CrossRef]

23. Osanai, Y.; Tissue, D.T.; Bange, M.P.; Anderson, I.C.; Braunack, M.V.; Singh, B.K. Plant-soil interactions and nutrient availability determine the impact of elevated CO2 and temperature on cotton productivity. Plant. Soil 2017, 410, 87-102. [CrossRef]

24. Tian, X.; Li, C.; Min, Z.; Wan, Y.; Xie, Z.; Chen, B.; Li, W.; Jorge, P.F. Biochar derived from corn straw affected availability and distribution of soil nutrients and cotton yield. PLoS ONE 2018, 13, e189924. [CrossRef]

25. Sadiq, S.A.; Baloch, D.M.; Ahmed, N.; Hidayatullah, K. Role of coal-derived humic acid in the availability of nutreints and growth of sunflower under calcareous soil. JAPS J. Anim. Plant. Sci. 2014, 24, 1737-1742.

26. Aziz, A.; Ashraf, M.; Sikandar, S.; Asif, M.; Akhtar, N.; Shahzad, S.M.; Wasaya, A.; Raza, A.; Babar, B.H. Optimizing sulfur for improving salt tolerance of sunflower (Helianthus annuus L.). Soil Environ. 2019, 38, 222-233. [CrossRef]

27. Rajeshwar, M.; Khan, M.A.A. Effect of biofertilizers on crop yield and soil available nutrients of rice and maize in alfisols of Nagarjuna Sagar left canal command area of Andhra Pradesh, India. Asian J. Soil Sci. 2010, 22, 159-175.

28. Tully, K.L.; Wood, S.A.; Almaraz, M.; Neill, C.; Palm, C. The effect of mineral and organic nutrient input on yields and nitrogen balances in western Kenya. Agric. Ecosyst. Environ. 2015, 214, 10-20. [CrossRef]

29. Oikeh, S.O.; Kling, J.G.; Okoruwa, A.E. Nitrogen Fertilizer Management Effects on Maize Grain Quality in the West African Moist Savanna. Crop. Sci. 1998, 38, 1056-1161. [CrossRef]

30. Aulakh, M.S.; Pasricha, N.S.; Sahota, N.S. Yield, nutrient concentration and quality of mustard crops as influenced by nitrogen and sulphur fertilizers. J. Agr. Sci.-Camb. 1980, 94, 545-549. [CrossRef]

31. Nederhof, A.J. Bibliometric monitoring of research performance in the Social Sciences and the Humanities: A Review. Scientometrics 2006, 66, 81-100. [CrossRef]

32. Zhang, H.; Liu, X.; Yi, J.; Yang, X.; Wu, T.; He, Y.; Duan, H.; Liu, M.; Tian, P. Bibliometric Analysis of Research on Soil Water from 1934 to 2019. Water 2020, 12, 1631. [CrossRef]

33. Mingze, W.; Dianfeng, L.; Jinglei, J.; Xiaoyi, Z. Global trends in soil monitoring research from 1999-2013: A bibliometric analysis. Acta Agric. Scand. 2015, 65, 483-495.

34. Jian, W.; Min, W.; Jin, Z.; Wu, J.; Sha, C.; Hao, T.; Qi, X.; Huang, S. A Bibliometric Analysis of Researches on Polycyclic Aromatic Hydrocarbons in Soil Environment Based on Web of Science. Shanghai Environ. Sci. 2016, 302, 112482.

35. Mao, G.; Shi, T.; Zhang, S.; Crittenden, J.; Guo, S.; Du, H. Bibliometric analysis of insights into soil remediation. J. Soil Sediment. 2018, 18, 2520-2534. [CrossRef] 
36. He, D.; Bristow, K.; Filipović, V.; Lv, J.; He, H. Microplastics in Terrestrial Ecosystems: A Scientometric Analysis. Sustainability 2020, 12, 8739. [CrossRef]

37. He, H.; Dyck, M.; Lv, J. The Heat Pulse Method for Soil Physical Measurements: A Bibliometric Analysis. Appl. Sci. 2020, 10, 6171. [CrossRef]

38. Stoops, G. The "Fabric" of soil micromorphological research in the 20th century-A bibliometric analysis. Geoderma 2014, 213, 193-202. [CrossRef]

39. Zhao, Q.L.; Wen-Ru, L.U. Research Review and Prospect of Soil Heavy Metals Pollution—Bibliometric Analysis Based on Web of Science. Environ. Sci. Technol. 2010, 33, 105-111.

40. Liu, Y.; Wu, K.; Zhao, R. Bibliometric analysis of research on soil health from 1999 to 2018. J. Soil Sediment. 2020, 20, 1-13. [CrossRef]

41. Prasad, M.N.V.; Pershell, K.; Koelmel, J. Bibliometric Analysis of Phytotechnologies for Remediation: Global Scenario of Research and Applications. Int. J. Phytoremediat. 2015, 17, 145-153.

42. Zhang, S.; Liu, X.; Huibin, D.; Guozhu, M.; Crittenden, J. Groundwater remediation from the past to the future: A bibliometric analysis. Water Res. J. Int. Water Assoc. 2017, 119, 114-125. [CrossRef]

43. Ho, Y. Some comments on: Mao et al. (2018) "Bibliometric analysis of insights into soil remediation" Journal of Soils and Sediments, 18(7): 2520-2534. J. Soil Sediment. 2019, 19, 3657-3658. [CrossRef]

44. Van Eck, N.J.; Waltman, L. Software survey: VOSviewer, a computer program for bibliometric mapping. Scientometrics 2010, 84 523-538. [CrossRef]

45. Shah, S.H.H.; Lei, S.; Ali, M.; Doronin, D.; Hussain, S.T. Prosumption: Bibliometric analysis using HistCite and VOSviewer. Kybernetes 2019, 49, 1020-1045. [CrossRef]

46. Niazi, M.A. Review of "CiteSpace: A Practical Guide For Mapping Scientific Literature" by Chaomei Chen. Complex. Adapt. Syst. Modeling 2016, 4, 23. [CrossRef]

47. Jain, Y.K.; Bhandare, S.K. Min Max Normalization Based Data Perturbation Method for Privacy. Int. J. Comput. Commun. 2013, 4, 233-238.

48. Raghunatha, R.R.L.; Shankarappa, T.H.; Shankar, R.K.; Satish, M.V. Review of Trends in Soil Fertility Research (2007-2016) using Scopus Database. Commun. Soil Sci. Plant. 2019, 50, 1063-1080.

49. Nyborg, M.; Solberg, E.D.; Izaurralde, R.C.; Malhi, S.S.; Molina-Ayala, M. Influence of long-term tillage, straw and N fertilizer on barley yield, plant-N uptake and soil-N balance. Soil Till. Res. 1995, 36, 165-174. [CrossRef]

50. Basso, B.; Ritchie, J.T. Impact of compost, manure and inorganic fertilizer on nitrate leaching and yield for a 6-year maize-alfalfa rotation in Michigan. Agric. Ecosyst. Environ. 2005, 108, 329-341. [CrossRef]

51. Yadav, R.L.; Dwivedi, B.S.; Prasad, K.; Tomar, O.K.; Shurpali, N.J.; Pandey, P.S. Yield trends, and changes in soil organic-C and available NPK in a long-term rice-wheat system under integrated use of manures and fertilisers. Field Crop. Res. 2000, 68, 219-246. [CrossRef]

52. Rahman, N.; Bruun, T.B.; Giller, K.E.; Magid, J.; Ven, G.W.J.; Neergaard, A. Soil greenhouse gas emissions from inorganic fertilizers and recycled oil palm waste products from Indonesian oil palm plantations. Gcb Bioenergy 2019, 11, 1056-1074. [CrossRef]

53. Sida, T.S.; Baudron, F.; Ndoli, A.; Tirfessa, D.; Giller, K.E. Should fertilizer recommendations be adapted to parkland agroforestry systems? Case studies from Ethiopia and Rwanda. Plant. Soil 2020, 453, 173-188. [CrossRef]

54. Rurangwa, E.; Vanlauwe, B.; Giller, K.E. The response of climbing bean to fertilizer and organic manure in the Northern Province of Rwanda. Exp. Agric. 2020, 56, 722-737. [CrossRef]

55. Giller, K.E.; Witter, E.; Mcgrath, S.P. Toxicity of heavy metals to microorganisms and microbial processes in agricultural soils: A review. Soil Biol. Biochem. 1998, 30, 1389-1414. [CrossRef]

56. Meena, R.S.; Lal, R.; Yadav, G.S. Long-term impact of topsoil depth and amendments on carbon and nitrogen budgets in the surface layer of an Alfisol in Central Ohio. Catena 2020, 194, 104752. [CrossRef]

57. Xu, Y.; Ding, X.; Lal, R.; Gao, X.; Li, S.; Sun, L.; Wang, Y.; Li, M.; Bai, S.; Wang, J. Effect of soil fertility on the allocation of nitrogen derived from different maize residue parts in the soil-plant system. Geoderma 2020, 379, 114632. [CrossRef]

58. Fan, M.; Lal, R.; Zhang, H.; Margenot, A.J.; Wu, J.; Wu, P.; Zhang, L.; Yao, J.; Chen, F.; Gao, C. Variability and determinants of soil organic matter under different land uses and soil types in eastern China. Soil Till. Res. 2020, 198, 104544. [CrossRef]

59. Lal, R. Soil Carbon Sequestration Impacts on Global Climate Change and Food Security. Science 2004, 304, 1623-1627. [CrossRef] [PubMed]

60. Lal, R. Soil carbon sequestration to mitigate climate change. Geoderma 2004, 123, 1-22. [CrossRef]

61. Arpenter, S.R.C.; Araco, N.F.C.; Orrell, D.L.C.; Owarth, R.W.H.; Harpley, A.N.S.; Mith, V.H.S. Nonpoint pollution of surface waters with phosphorus and nitrogen. Ecol. Appl. 1998, 8, 559-568. [CrossRef]

62. Sharpley, A.N.; Chapra, S.C.; Wedepohl, R.; Sims, J.T.; Daniel, T.C.; Reddy, K.R. Managing Agricultural Phosphorus for Protection of Surface Waters: Issues and Options. J. Environ. Qual. 1994, 23, 437-451. [CrossRef]

63. Brennan, R.B.; Murnane, J.G.; Sharpley, A.N.; Herron, S.; Brye, K.R.; Simmons, T. Soil phosphorus dynamics following land application of unsaturated and partially saturated red mud and water treatment residuals. J. Environ. Manag. 2019, $248,109296$. [CrossRef] [PubMed]

64. Dodd, R.J.; Sharpley, A.N.; Berry, L.G. Organic Phosphorus Can Make an Important Contribution to Phosphorus Loss from Riparian Buffers. Agric. Environ. Lett. 2018, 3, 180002. [CrossRef] 
65. Bolster, C.H.; Baffaut, C.; Nelson, N.O.; Osmond, D.L.; Cabrera, M.L.; Ramirez-Avila, J.J.; Sharpley, A.N.; Veith, T.L.; McFarland, A.M.S.; Senaviratne, A.G.M.M.; et al. Development of PLEAD: A Database Containing Event-based Runoff Phosphorus Loadings from Agricultural Fields. J. Environ. Qual. 2019, 48, 510-517. [CrossRef] [PubMed]

66. Geng, R.; Yin, P.; Sharpley, A.N. A coupled model system to optimize the best management practices for nonpoint source pollution control. J. Clean Prod. 2019, 220, 581-592. [CrossRef]

67. Ying, Z.; Shengyan, P.; Xue, L.; Ya, G.; Long, G. Global trends and prospects in microplastics research: A bibliometric analysis. J. Pre-Proof 2020, 400, 123110.

68. Khan, S.A.; Mulvaney, R.L.; Ellsworth, T.R.; Boast, C.W. The Myth of Nitrogen Fertilization for Soil Carbon Sequestration. J. Environ. Qual. 2007, 36, 1821-1832. [CrossRef] [PubMed]

69. Smil, V. Nitrogen in crop production: An account of global flows. Glob. Biogeochem. Cycles 1999, 13, 647-662. [CrossRef]

70. Crews, T.E.; Peoples, M.B. Legume versus fertilizer sources of nitrogen: Ecological tradeoffs and human needs. Agric. Ecosyst. Environ. 2004, 102, 279-297. [CrossRef]

71. Jaynes, D.B.; Colvin, T.S.; Karlen, D.L.; Cambardella, C.A.; Meek, D.W. Nitrate Loss in Subsurface Drainage as Affected by Nitrogen Fertilizer Rate. Surf. Water Qual. 2001, 1305-1314. [CrossRef] [PubMed]

72. Lambers, H.; Raven, J.; Shaver, G.; Smith, S. Plant nutrient-acquisition strategies change with soil age. Trends Ecol. Evol. 2008, 23, 95-103. [CrossRef]

73. Ehrenfeld, J.G. Effects of Exotic Plant Invasions on Soil Nutrient Cycling Processes. Ecosystems 2003, 6, 503-523. [CrossRef]

74. Richardson, A.E.; Barea, J.; McNeill, A.M.; Prigent-Combaret, C. Acquisition of phosphorus and nitrogen in the rhizosphere and plant growth promotion by microorganisms. Plant. Soil 2009, 321, 305-339. [CrossRef]

75. Andre, B.; Job, K.; Vanlauwe, B.; Waswa, B.; Kimetu, J. Soil organic carbon dynamics, functions and management in West African agro-ecosystems. SienceDirect 2005, 94, 13-25.

76. Wezel, A.J.; Rajot, L.; Herbrig, H. Influence of shrubs on soil characteristics and their function in Sahelian agro-ecosystems in semi-arid Niger. J. Arid Environ. 2000, 44, 383-398. [CrossRef]

77. Bationo, A.; Baethgen, W.E.; Christianson, C.B.; Mokwunye, A.U. Comparison of five soil testing methods to establish phosphorus sufficiency levels in soil fertilized with water-soluble and sparingly soluble-P sources. Fertil. Res. 1991, 28, 271-279. [CrossRef]

78. Bationoa, A.; Lompob, F.; Koala, S. Research on nutrient ows and balances in west Africa: State-of-the-art. Agric. Ecosyst. Environ. 1998, 71, 19-35.

79. Uzoma, K.C.; Inoue, M.; Andry, H.; Fujimaki, H.; Zahoor, A.; Nishihara, E. Effect of cow manure biochar on maize productivity under sandy soil condition. Soil Use Manag. 2011, 27, 205-212. [CrossRef]

80. Bhattacharyya, R.; Chandra, S.; Singh, R.; Kudu, S.; Srivastva, A.; Gupta, H. Long-term farmyard manure application effects on properties of a silty clay loam soil under irrigated wheat-soybean rotation. Soil Till. Res. 2007, 94, 386-396. [CrossRef]

81. Hammesfahr, U.; Heuer, H.; Manzke, B.; Smalla, K.; Thiele-Bruhn, S. Impact of the antibiotic sulfadiazine and pig manure on the microbial community structure in agricultural soils. Soil Biol. Biochem. 2008, 40, 1583-1591. [CrossRef]

82. Alexander, R.B.; Smith, R.A.; Schwarz, G.E.; Boyer, E.W.; Nolan, J.V.; Brakebill, J.W. Differences in Phosphorus and Nitrogen Delivery to The Gulf of Mexico from the Mississippi River Basin. Environ. Sci. Technol. 2008, 42, 822-830. [CrossRef] [PubMed]

83. Tonitto, C.; David, M.B.; Drinkwater, L.E. Replacing bare fallows with cover crops in fertilizer-intensive cropping systems: A meta-analysis of crop yield and N dynamics. Agric. Ecosyst. Environ. 2006, 112, 58-72. [CrossRef]

84. Bernal, M.P.; Alburquerque, J.A.; Moral, R. Composting of animal manures and chemical criteria for compost maturity assessment. A review. Bioresour. Technol. 2009, 100, 5444-5453. [CrossRef] [PubMed]

85. Lehmann, J.; Rillig, M.C.; Thies, J.; Masiello, C.A.; Hockaday, W.C.; Crowley, D. Biochar effects on soil biota-A review. Soil Biol. Biochem. 2011, 43, 1812-1836. [CrossRef]

86. Chang, E.; Chung, R.; Tsai, Y. Effect of different application rates of organic fertilizer on soil enzyme activity and microbial population. Soil Sci. Plant. Nutr. 2007, 53, 132-140. [CrossRef]

87. Berg, G.; Smalla, K. Plant species and soil type cooperatively shape the structure and function of microbial communities in the rhizosphere. Fems. Microbiol. Ecol. 2009, 68, 1-13. [CrossRef] [PubMed]

88. Zimmerman, A.R.; Gao, B.; Ahn, M. Positive and negative carbon mineralization priming effects among a variety of biocharamended soils. Soil Biol. Biochem. 2011, 43, 1169-1179. [CrossRef]

89. Fierer, N. Embracing the unknown: Disentangling the complexities of the soil microbiome. Nat. Rev. Microbiol. 2017, 15, 579-590. [CrossRef]

90. Laird, D.; Fleming, P.; Wang, B.; Horton, R.; Karlen, D. Biochar impact on nutrient leaching from a Midwestern agricultural soil. Geoderma 2010, 158, 436-442. [CrossRef]

91. Laird, D.A.; Fleming, P.; Davis, D.D.; Horton, R.; Wang, B.; Karlen, D.L. Impact of biochar amendments on the quality of a typical Midwestern agricultural soil. Geoderma 2010, 158, 443-449. [CrossRef]

92. Francis, C.A.; Harwood, R.R.; Parr, J.F. The potential for regenerative agriculture in the developing world. Am. J. Altern. Agric. 1986, 1, 65-74. [CrossRef] 